\title{
The Effect of Weed Competition on Apple Fruit Quality
}

\author{
Ersin ATAY ${ }^{1 *}$, Seckin GARGIN ${ }^{1}$, Ahmet ESITKEN ${ }^{2}$, N. Pinar GUZEL ${ }^{3}$, \\ A. Nilgun ATAY ${ }^{1}$, Mesut ALTINDAL ${ }^{1}$, Hamza SENYURT ${ }^{1,3}$, Meltem EMRE $^{1}$
}

\author{
${ }^{I}$ TAGEM Fruit Research Institute, 32500, Egirdir, Isparta, Turkey; ersin.atay@tarim.gov.tr ( ${ }^{*}$ corresponding author); \\ seckin.gargin@tarim.gov.tr;aysenilgun.atay@tarim.gov.tr;mesut.altindal@tarim.gov.tr; \\ hamza.senyurt@tarim.gov.tr; meltem.emre@tarim.gov.tr \\ ${ }^{2}$ Selcuk University, Faculty of Agriculture, Department of Horticulture, 42030, Konya, Turkey; aesitken@selcuk.edu.tr \\ ${ }^{3}$ TAGEM Plant Protection Central Research Institute, 06172, Ankara, Turkey; nuranpinar.guzel@tarim.gov.tr
}

\begin{abstract}
Orchard performance is influenced by weed competition. In this study, the effects of weed competition on nutrient contents, chemical and physical fruit quality properties were sought. The study was carried out in a high-density apple orchard ('Golden Delicious'/M.9) over two consecutive growing seasons. The effect of weed competition was studied at three different levels: weak, moderate and strong. Fruit firmness, soluble solids content, macronutrients (such as nitrogen, potassium and calcium) and potassium+magnesium/calcium ratio in fruit were significantly affected by weed competition. Strong weed competition negatively affected soluble solids content and potassium+magnesium/calcium ratio. In both trial years, soluble solids content was significantly higher in weak weed competition. In the first year of the study, soluble solids content ranged between $13.77 \pm 0.06 \%$ (strong weed competition) and $15.20 \pm 0.10 \%$ (weak weed competition). In the following year, soluble solids content values were determined as $13.13 \pm 0.23 \%$ in strong weed competition and $13.83 \pm 0.21 \%$ in weak weed competition. Weak weed competition showed superiority for fruit weight and potassium+magnesium/calcium ratio. As a whole, this study indicates that insufficient weed control in tree rows might be a limiting factor for fruit quality in high-density apple orchards.
\end{abstract}

Keywords: bitter pit, ground cover, Malus $\times$ domestica, micronutrient, weed suppression

\section{Introduction}

The techniques (e.g. mechanical, chemical and cultural) and strategies for managing orchard-floor (both tree rows and alleyways) and soil resources in fruit growing are referred to as orchard-floor management (OFM) systems (Houge and Neilsen, 1987; Singh et al., 2016). The OFM systems used to manage competition between weeds and fruit trees are crucial for root development, tree performance, fruit set, storage life, soil and leaf nutrients, soil structure, soil temperature, tree water status, soil water retention, soil organic matter, enzyme and microbial activity, mycorrhizal fungi and soil microbial community composition, water and nutrient availability, insects, small mammals, root and replant diseases, and erosion and pollution (Merwin and Stiles, 1994; Merwin, 2003; Yao et al., 2005; St Laurent et al., 2008; Potter et al., 2012; Meyers et al., 2014; Neilsen et al., 2014; Slatnar et al., 2014; Fisk et al., 2015; Meyer et al., 2015; Tahir et al., 2015; Singh et al., 2016). Weed competition for resources with fruit trees stunt the tree's growth in young orchards and often reduce the quantity and quality of yields in mature trees (Merwin and Stiles, 1994;
Merwin, 2003; Sharifi et al., 2016). Practical knowledge about the effects of weed competition on fruit quality in the orchard is highly crucial for fruit growers. Fruit quality is poorly considered by solely fruit size and skin colour (Crisosto and Costa, 2008). In fact, fruit quality determined by genetic, cultural and environmental factors is a concept including a large number of criteria such as sensory properties (e.g. appearance, taste and aroma), health benefits (e.g. antioxidants), nutritional properties (e.g. nutrients), pesticide residues and defects (e.g. bitter pit) (Crisosto and Costa, 2008; Atay et al., 2010). The complete elimination of weed competition in orchards is possible with residual herbicides, but it may not be desirable for economic and environmental reasons (Merwin, 2003). Existing knowledge is not satisfactory enough to explicitly indicate the effect of weed competition on fruit quality properties such as nutrient contents. From this viewpoint, this study shows the effects of weak, moderate and strong weed competition on fruit nutrient contents, chemical (i.e. SSC and $\mathrm{pH}$ ) and physical (i.e. weight, firmness and skin colour) fruit quality properties in a high-density apple orchard over two subsequent years. 


\section{Materials and Methods}

\section{Experimental site and plant materials}

This study was conducted at Fruit Research Institute (MAREM), Isparta, Turkey (http://arastirma.tarim.gov.tr/ marem). 'Golden Delicious' cultivar on M.9 rootstock was used as plant material. The orchard was planted in spring 2005 at an in-row spacing of $1 \mathrm{~m}$ with $3.5 \mathrm{~m}$ between rows. Trees were trained to a vertical axis and supported by a trellis system. 'Red Delicious' was planted as pollinator cultivar in the orchard. There was no pollination problem during the trial considered, and any blossom thinning was not performed over two trial years. Hand-thinning after the physiological drop was managed according to local crop husbandry practices when crop load exceeded 4.5 fruit per $\mathrm{cm}^{2}$ of branch cross-sectional area. There was a relatively high yield in 2012 compared to 2011. Thus, 'Golden Delicious' is susceptible to the biennial bearing (Atay et al., 2013a). Trees were fertilized according to soil analyses with drip irrigation water at regular intervals. All other agricultural practices were provided according to commercial procedures in the region.

\section{Weed competition level}

Mowing in the alleyways between tree rows was maintained with a tractor-mounted mower when needed, which was standard in all weed competition levels. Mowing in tree rows was carried out with a grass cutter mower of $0.5 \mathrm{~m}$ on either side of the trees. Details for weed species of the study area have been described elsewhere (Atay et al., 2013b). Mowing to $1-5 \mathrm{~cm}$, to eliminate existing weed competition in tree rows, was carried out at the following intervals: April through October - hereafter referred to as 'Weak Weed Competition (WWC)', April+May+June hereafter referred to as 'Moderate Weed Competition (MWC)'. Mowing in May was done one month later from first bloom in April, and the next mowing was applied at an interval of 1-month. In 'Strong Weed Competition (SWC)', weeds were not treated throughout the trial. The mowing applications were practiced over three subsequent years, 2010-2012, using the same methodology and trees, and the data were collected in last couple years of the trial (2011 and 2012).

\section{Data collection}

On a set of 30 fruit taken from randomly for each weed competition level, fruit weight $(\mathrm{g})$, fruit firmness $\left(\mathrm{kg} \mathrm{cm}^{-2}\right)$, soluble solids content - SSC (\%), $\mathrm{pH}$ and fruit skin colour were measured as described by Atay (2015). In summary, fruit weight was measured by a digital scale sensitive to $0.01 \mathrm{~g}$. Fruit firmness was measured on opposing sides of peeled fruit by a hand-held penetrometer (Effegi, Italy) with an $11.1-\mathrm{mm}$ probe. SSC by a digital refractometer (Hanna, HI 96801, USA) and $\mathrm{pH}$ by a digital $\mathrm{pH}$ meter (Hanna, HI $2211 \mathrm{pH}$ /ORP meter, USA) were measured in fruit juice. Fruit skin colour values ( $b^{*}$ here) were measured with a colorimeter (Minolta CR-400, Japan). The values of b* can be positive (' + ' = yellow) or negative (' - ' = blue) (Alcobendas et al., 2012). On a sample of 30 fruit taken from the 75-80 mm size class for each weed competition level, fruit nutrient contents were determined. The fruit, initially, were decontaminated and rinsed with tap water, $2 \mathrm{~N} \mathrm{HCl}$, and distilled water. Then, samples were dried at $70{ }^{\circ} \mathrm{C}$ until constant weight and then ground for sieving. The total nitrogen $(\mathrm{N})$ was determined using the Kjeldahl method with a distillation unit
(Gerhardt, Königswinter, Germany). Contents of phosphorus (P) potassium $(\mathrm{K})$, calcium $(\mathrm{Ca})$, magnesium $(\mathrm{Mg})$, iron $(\mathrm{Fe})$, manganese $(\mathrm{Mn})$, copper $(\mathrm{Cu})$ and boron $(\mathrm{B})$ were determined with an inductively coupled plasma spectrometer (Perkin-Elmer, Optima 2100 DV Optical Emission Spectrometer, Shelton, CT 06 484, USA). $\mathrm{K}+\mathrm{Mg} / \mathrm{Ca}$ ratio was calculated. The contents of macro- (N, P, K, Ca and Mg) and micronutrients (Fe, Mn, Cu, B and $\mathrm{Zn}$ ) in fruit tissues were expressed on a dry-mass basis.

\section{Data analysis}

The experiment was conducted in three tree rows. Weed competition levels were employed with the factorial randomised block design. Each weed competition level had three replications of 4 experimental trees (i.e. $4 \times 3=12$ trees in total per weed competition level), and those on either side acted as guard trees between the different weed competition levels. Data were subjected to analysis of variance (ANOVA) procedures. When the $F$-test statistics were significant in ANOVA, means were separated using Least Significant Difference (LSD) multiple comparison test. In all analyses threshold for statistical significance was set at $P \leq 0.05$. Associated $P$-values were figured in the paper. Data were analyzed using SAS-JMP software version 7.0 (http://www.jmp.com/ software/).

\section{Results and Discussion}

The interactions between weed competition level and year were significant for fruit weight (Fig. 1A), SSC (Fig. 1C) and $\mathrm{pH}$ (Fig. 1D). In this manner, results suggest that year effect, determined by many internal and external factors, has a considerable impact on these properties.

Weed competition level showed a significant effect on fruit firmness in 2012, and it was lower $(7.79 \pm 0.52 \mathrm{~kg})$ in SWC than others (Fig. 1B). It can be speculated that this situation is likely a result of a not enough $\mathrm{N}$ content in fruit from SWC. The firmness is mainly determined by the number and size of cells in fruit cortex (Faust, 1989). The fruit with a large number of small cells are more likely to be firmer than those having sizeable fewer cells (Westwood, 1995). The practices increasing cell number in fruit may promote firmness. During the cell division period, the most notably determining factor is the $\mathrm{N}$ content of trees accumulated in the previous year (Millard, 1996; Neilsen et al., 2001).

SSC was lower in SWC than others in both trial years (Fig. 1C). The dry-matter transport into fruit from leaves is relatively efficient after the time when the vegetative growth is ceased that generally coincide with the first half of July in the northern hemisphere (Faust, 1989; Westwood, 1995). The SWC after July might be hindered the accumulation of nutrients in the leaf that limits photosynthesis. In such situations, the leaves with a low dry-matter accumulation have a limited capacity to transport dry-matter into fruit.

Weed competition level did not significantly impact on fruit skin colour in both trial years (Fig. 1E). Fruit in 2011 had a higher $b^{*}$ values than 2012 in all weed competition levels, which indicates that fruit in 2011 had a deeper yellow colour on 2012.

There was a significant interaction between weed competition level and year for N (Fig. 2A) and K (Fig. 2C) in fruit, which confers a year-to-year effect. Effect of weed competition level was significant for Ca in 2011 (Fig. 2D) and 
122

for $\mathrm{P}$ in 2012 (Fig. 2B). Ca content was higher in WWC than in the other two weed competition levels (Fig. 2D). Ca uptake into fruit occurs in the first several weeks of the growing season, and there are complex relationships between shoot growth, crop load, fruit size, dilution, and seed number for Ca (Lakso, 2003; Saure, 2005; Atay et al., 2013c).

Concerning $\mathrm{K}+\mathrm{Mg} / \mathrm{Ca}$ ratio, relatively higher values in both trial years were calculated in SWC without being significantly different from the other weed competition levels (Fig. 2F). The values for $\mathrm{K}+\mathrm{Mg} / \mathrm{Ca}$ ratio were higher in 2011 than in 2012 in all weed competition levels. The reason for this distinct differences between years for $\mathrm{K}+\mathrm{Mg} / \mathrm{Ca}$ ratio probably lies in the associated differences in the crop load of trees. As mentioned in material and methods, 'Golden Delicious' has a strong tendency to the biennial bearing (Atay et al., 2013a), and yield was lower in 2011 than in 2012 in the trial orchard. In
2011, relatively low Ca content in fruit was recorded. In contrary, in 2012, a higher crop load resulted in an increase in Ca content in fruit. A low crop load promotes vegetative growth, leading to an increase in shoot growth (Tromp, 2005). Regarding the vigorously growing trees in low-crop years, $\mathrm{Ca}$ taken from soil is used to the growth of newly developing shoots, which may reduce Ca content in fruit. Thus, Ca taken from soil is firstly transported to newly developing shoot-tip leaves (Shear and Faust, 1970; Ford and Quinlan, 1979). In 2012, the total vegetative growth of trees might be reduced by a relatively high crop load, which may lead to an increase in the transport of $\mathrm{Ca}$ from roots to fruit. With referenced to Saure (2005), vigorous shoot growth accompanied by low crop load leads a decrease of $\mathrm{Ca}$ in fruit. A low Ca content in fruit tissues may result in a higher bitter pit incidence, a calcium-related physiological disorder (Watkins, 2003). It is well known that in

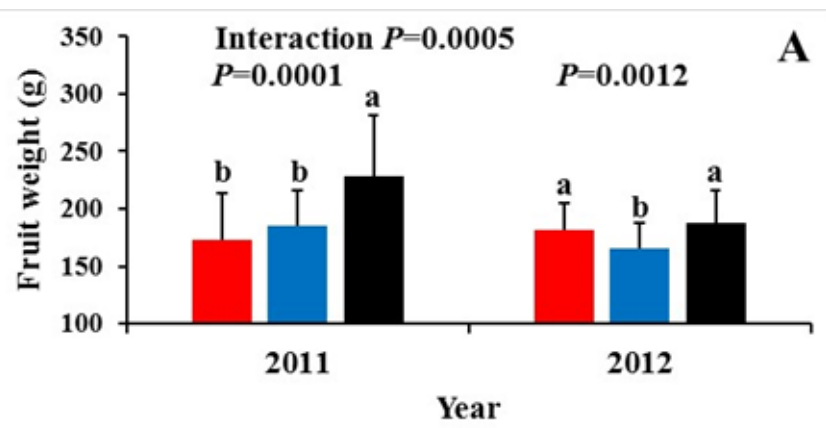

$\because$ SWC $\backsim$ MWC $₫ W W C$

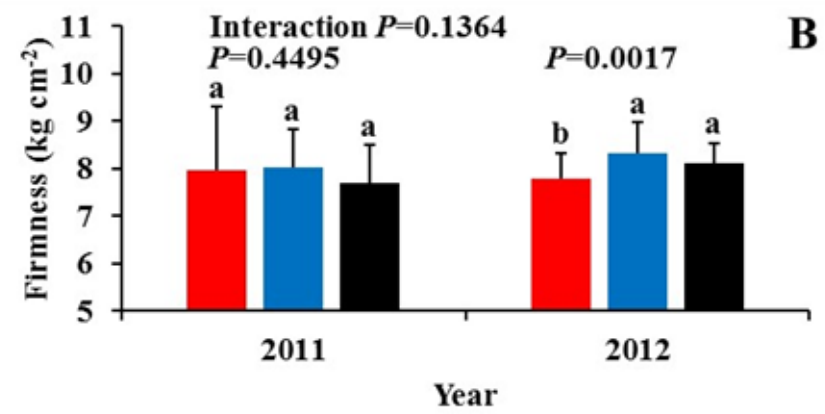

$\because$ SWC $\square \mathrm{MWC}=\mathrm{WWC}$

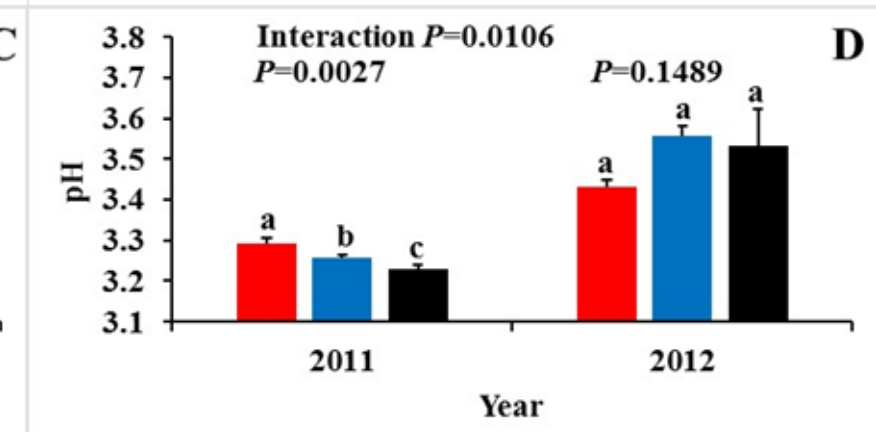

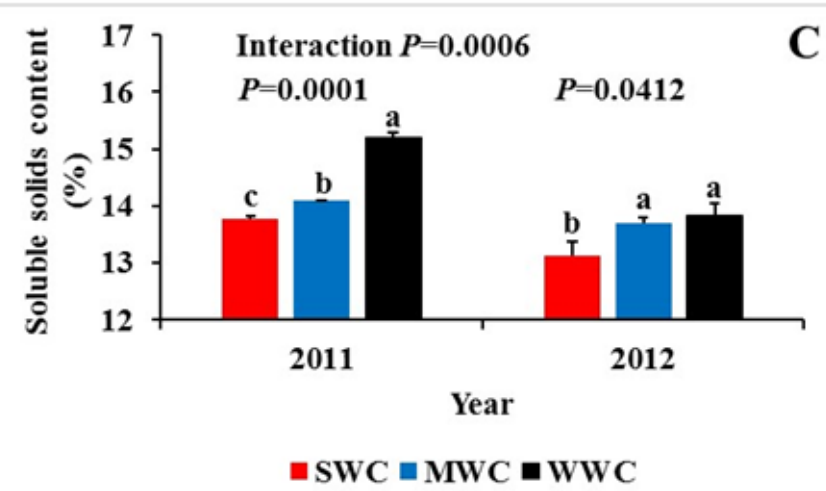

$\square$ SWC $\square$ MWC $\square W W C$

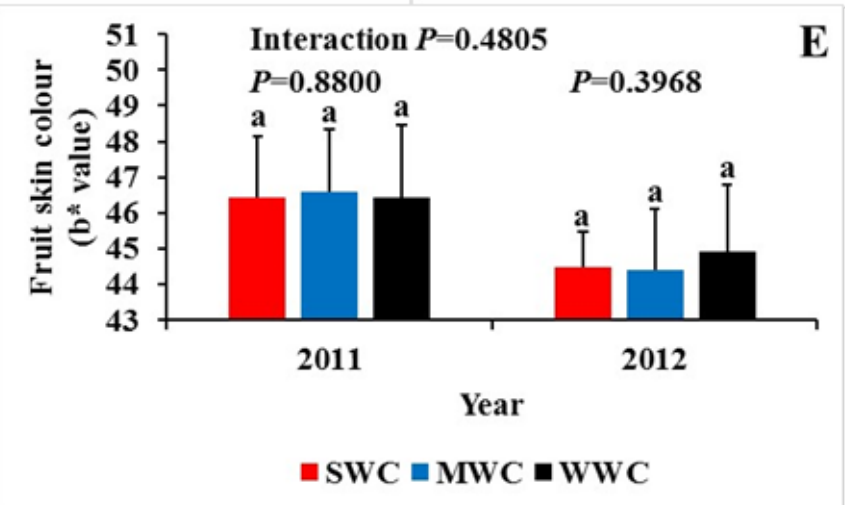

Fig. 1. Effect of weed competition on physical and chemical fruit quality properties (A) fruit weight $(n=30),(\mathrm{B})$ firmness $(n=30)$, (C) soluble solids content (SSC) ( $n=3),(\mathrm{D}) \mathrm{pH}(n=3)$, and (E) fruit skin colour (b* value; ' + ' = yellow, '-' = blue) ( $n=30)$. SWC: Strong Weed Competition, MWC: Moderate Weed Competition, WWC: Weak Weed Competition. Interaction $P: P$-value of the interaction between weed competition level $\times$ year (2011 and 2012). Within each year, different letters indicate significant differences at $P \leq 0.05$. The values shown are means \pm standard deviation (SD) 


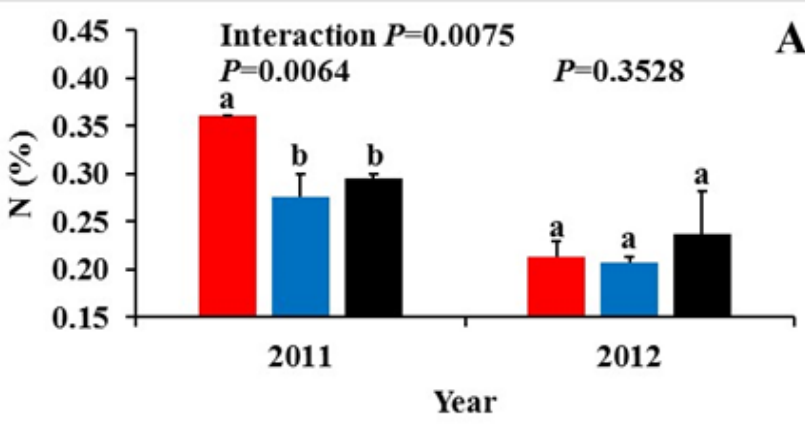

$\square$ SWC $\square$ MWC $₫ W W C$

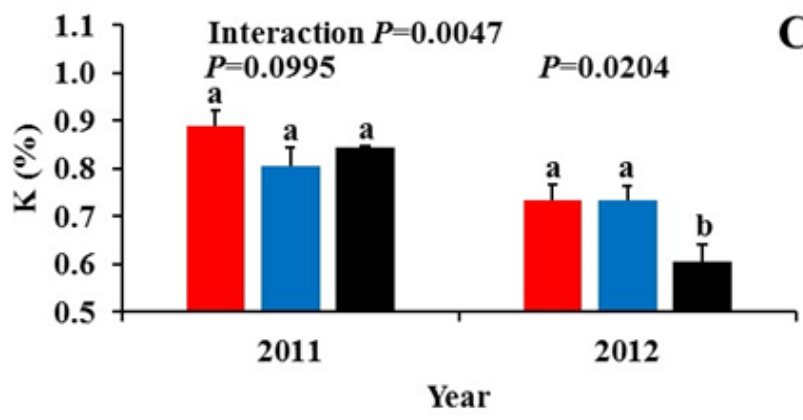

घWC $\backsim \mathrm{MWC} \backsim \mathrm{WWC}$

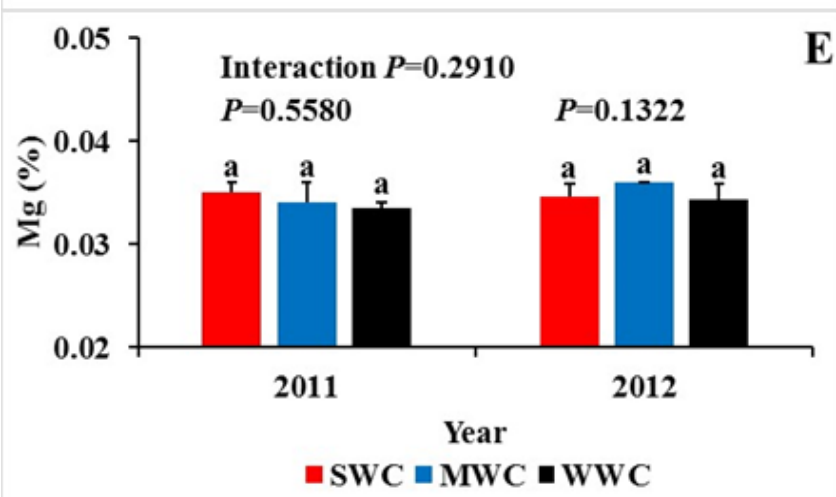

$\mathbf{A}$

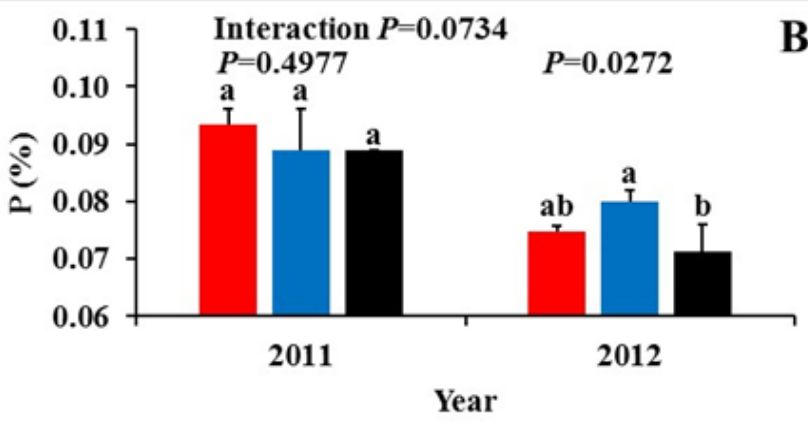

$\square$ SWC $\backsim$ MWC $\square W W C$

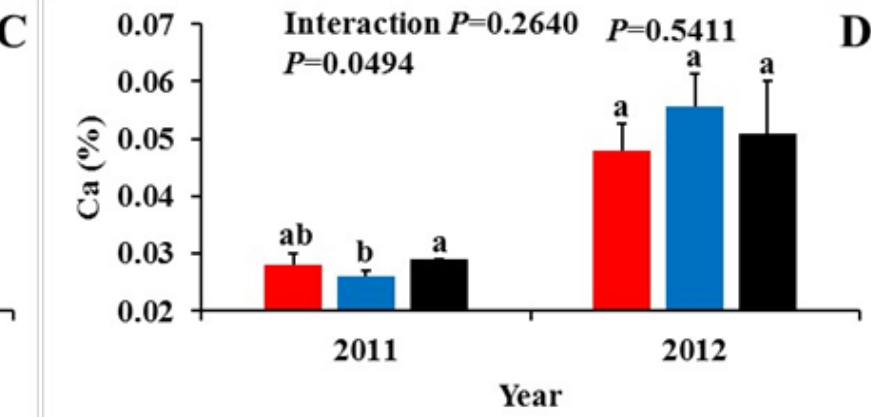

$\because \mathrm{SWC} \backsim \mathrm{MWC} \backsim \mathrm{WWC}$

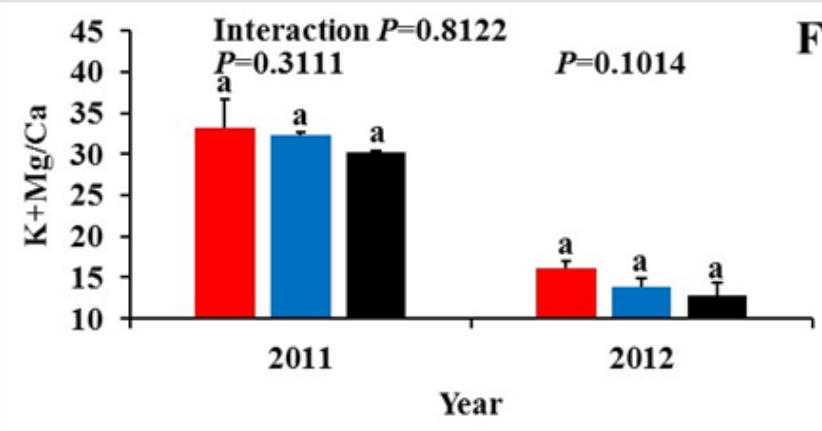

$\because$ SWC $\because \mathrm{MWC} \backsim \mathrm{WWC}$

Fig. 2. Effect of weed competition on macronutrient contents in fruit (A) N: nitrogen ( $n=3)$, (B) P: phosphorus $(n=3)$, (C) K: potassium (n=3), (D) Ca: calcium ( $n=3)$, (E) Mg: magnesium ( $n=3)$, and $\mathrm{K}+\mathrm{Mg} / \mathrm{Ca}(n=3)$. SWC: Strong Weed Competition, MWC: Moderate Weed Competition, WWC: Weak Weed Competition. Interaction $P: P$-value of the interaction between weed competition level $\mathrm{x}$ year (2011 and 2012). Within each year, different letters indicate significant differences at $P \leq 0.05$. The values shown are means \pm SD

addition to $\mathrm{Ca}$ in fruit, $\mathrm{K}$ and $\mathrm{Mg}$ contents are related to bitter pit incidence in apple. Therefore, $\mathrm{K}+\mathrm{Mg} / \mathrm{Ca}$ ratio in the apple fruit has great importance for bitter pit incidence. A low ratio of $\mathrm{K}+\mathrm{Mg} / \mathrm{Ca}$ reduce bitter pit incidence following storage (Faust, 1989). Weed-crop competition for soil nutrients may not favorable for fruit trees, because the root density of fruit trees is lower than that of the weeds. In the orchards with a permanent ground cover all year round, competition between weeds and trees may negatively influence tree performance on nutrition uptake (Merwin, 2003; Webster, 2005). As a result of intense weed competition, the fruit contain relatively less calcium, which leads to a higher ratio of $\mathrm{K}+\mathrm{Mg} / \mathrm{Ca}$. Moreover, large fruit are more prone to bitter pit than small ones. However, in the current study, WWC had higher values for average fruit weight in both trial years (Fig. 1A), and additionally, the nutrients in fruit were determined in the same size class $(75-80 \mathrm{~mm})$ in all weed competition levels. Therefore, the eliminating of weed competition during the growth season seems to be advisable to apple growers because WWC provided lower $\mathrm{K}+\mathrm{Mg} / \mathrm{Ca}$ ratios in both trial years in this study.

The interactions between weed competition level and year were significant for $\mathrm{Zn}$ (Fig. 3D) and B (Fig. 3E) in fruit. Weed competition did not significantly affect other micronutrients $\mathrm{Fe}$ (Fig. 3A), $\mathrm{Cu}$ (Fig. 3B) and $\mathrm{Mn}$ (Fig. 3C) in both trial years.

\section{Conclusions}

To conclude, the findings showed that year-to-year effect had a significant impact on some fruit quality properties (fruit weight, SSC, $\mathrm{pH}, \mathrm{N}, \mathrm{K}, \mathrm{Zn}$ and $\mathrm{B}$ ). SSC and $\mathrm{K}+\mathrm{Mg} / \mathrm{Ca}$ ratio, 

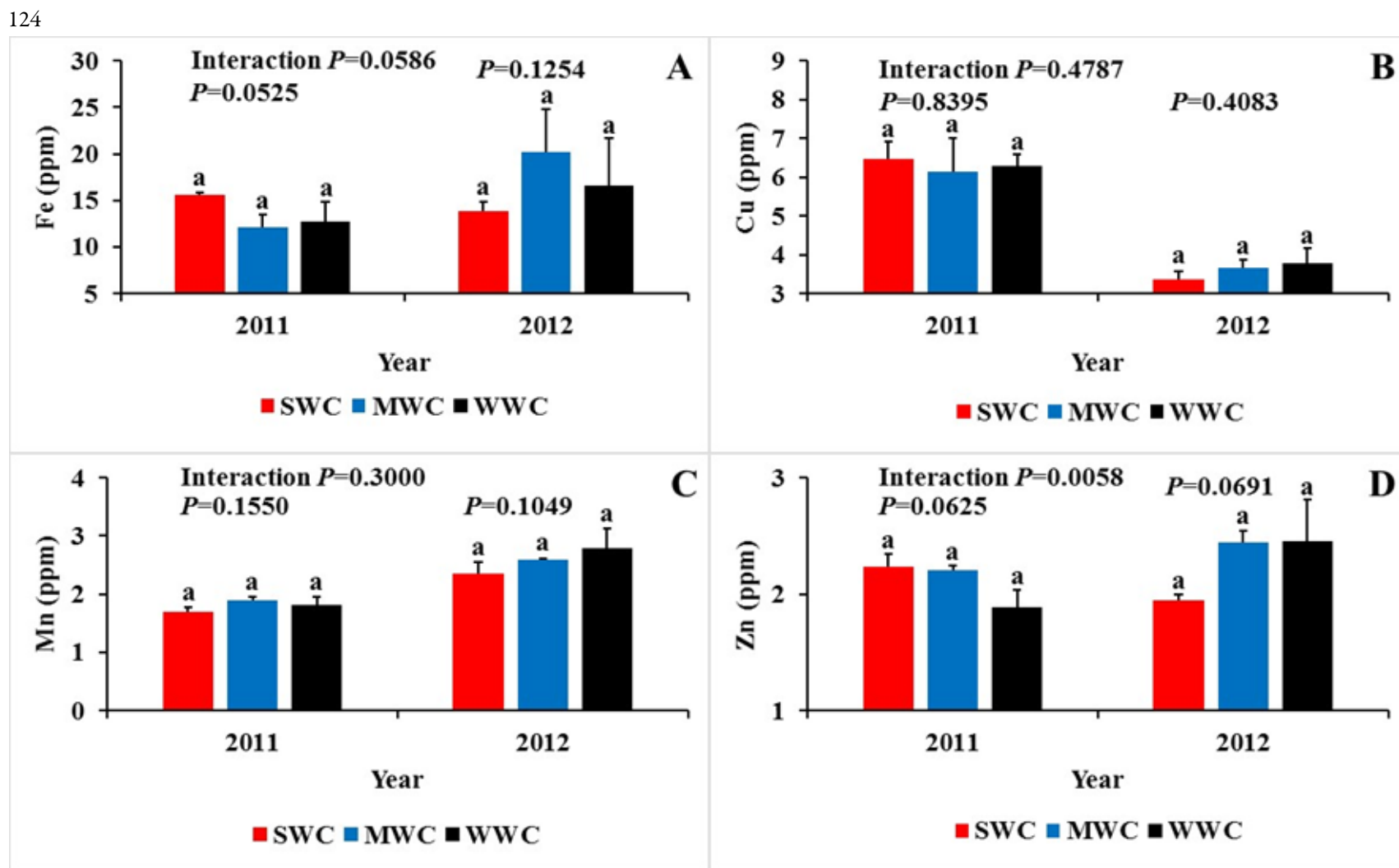

$\because \mathrm{SWC} \backsim \mathrm{MWC} \backsim \mathrm{WWC}$

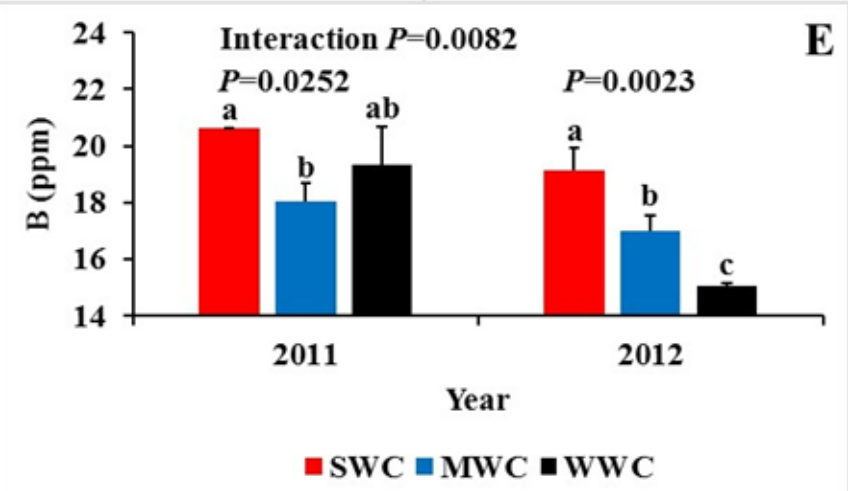

Fig. 3. Effect of weed competition on micronutrient contents in fruit (A) Fe: iron (n=3), (B) Cu: copper (n=3), (C) Mn: manganese $(n=3)$, (D) Zn: zinc $(n=3)$, and (E) B: boron $(n=3)$. SWC: Strong Weed Competition, MWC: Moderate Weed Competition, WWC: Weak Weed Competition. Interaction $P$ : $P$-value of the interaction between weed competition level x year (2011 and 2012). Within each year, different letters indicate significant differences at $P \leq 0.05$. The values shown are means \pm SD

commercially important fruit quality properties in the apple industry, were negatively influenced by SWC. The weed competition, in general, did not effect on micronutrient concentrations. WWC has provided superior results for fruit weight, SSC and $\mathrm{K}+\mathrm{Mg} / \mathrm{Ca}$ ratio.

\section{Acknowledgements}

This work was supported by TAGEM (General Directorate of Agricultural Research and Policy of Turkey).

\section{References}

Alcobendas R, Miras-Avalos JM, Alarcon JJ, Pedrero F, Nicolas E (2012).
Combined effects of irrigation, crop load and fruit position on size, color and firmness of fruits in an extra-early cultivar of peach. Scientia Horticulturae 142:128-135.

Atay E, Pirlak L, Atay AN (2010). Determination of fruit growth in some apple varieties. Tarm Bilimleri Dergisi - Journal of Agricultural Sciences 16(1):1-8

Atay AN, Koyuncu F, Atay E (2013a). Relative susceptibility of selected apple cultivars to alternate bearing. Journal of Biological and Environmental Sciences 7(20):81-86.

Atay E, Guzel P, Gargin S, Esitken A, Senyurt H, Atay AN, Altindal M, Calhan O (2013b). Determination of important parameters for weed control in intensive apple orchards: weed species and its density. IOBC/WPRSBulletin 91:439-442. 
Atay E, Butar S, Gargin S, Atay AN, Altindal M, Yalcin B (2013c) Elmalarda merkezi lider terbiye sisteminde dal katlari ve meyve kalitesi arasindaki iliskiler [Relations between branch-tiers and fruit quality in central leader training system for apples]. Anadolu Journal of Agricultural Sciences 28(2):67-70.

Atay E (2015). Effect of application time of prohydrojasmon on fruit coloration of 'Gala' and 'Braeburn' apples. Bulgarian Journal of Agricultural Science 21(6):1242-1247.

Crisosto CH, Costa G (2008). Preharvest factors affecting peach quality. In: Layne DR, Bassi D (Eds). The peach: botany, production and uses. CABI Publishing, Cambridgepp 536-549.

Faust M (1989). Physiology of temperate fruit trees. John Willey \& Sons, USA.

Fisk CL, Parker ML, Mitchem W (2015). Vegetation-free width and irrigation impact peach tree growth, fruit yield, fruit size, and incidence of hemipteran insect damage. HortScience 50(5):699-704.

Ford EM, Quinlan JD (1979). The distribution of ${ }^{45} \mathrm{Ca}$ in apple fruits when supplied to the roots at three times during the season. Journal of Horticultural Science 54:181-188.

Houge EJ, Neilsen GH (1987). Orchard floor vegetation management. Horticultural Reviews 9:377-430.

JMP Development Group (2007). JMP Statistics and Graphics Guide, Version 7.0 (SAS Institute, Cary, NC).

Lakso A (2003). Water relations of apples. In: Ferree DC, Warrington IJ (Eds). Apples: botany, production and uses. CABI Publishing, Cambridge pp 167-194.

Merwin IA, Stiles WC (1994). Orchard groundcover management impacts on apple tree growth and productivity, and soil nutrient availability and uptake. Journal of the American Society for Horticultural Science 119:216-222.

Merwin IA (2003). Orchard-floor management systems. In: Ferree DC, Warrington IJ (Eds). Apples: botany, production and uses. CABI Publishing, Cambridge pp 303-318.

Meyer AH, Wooldridge J, Dames JF (2015). Effect of conventional and organic orchard floor management practices on enzyme activities and microbial counts in a 'Cripp's Pink'/M7 apple orchard. South African Journal of Plant andSoil 32(2):105-112

Meyers SL, Jennings KM, Monks DW, Mitchem WE (2014). Effect of weed-free strip width on newly established 'Navaho' blackberry growth, yield, and fruit quality. Weed Technology 28:426-431.

Millard P (1996). Ecophysiology of internal cycling of nitrogen for tree growth. Journal of Plant Nutrition and Soil Science 159:1-10.

Neilsen D, Millard P, Herbert LC, Neilsen GH, Houge EJ, ParchomchukP, Zebarth BJ (2001). Remobilization and uptake of $\mathrm{N}$ by newly planted apple (Malus domestica) trees in response to irrigation method and timing of Napplication. Tree Physiology 21(8):513-521.
Neilsen G, Forge T, Angers D, Neilsen D, HogueE (2014). Suitable orchard floor management strategies in organic apple orchards that augment soil organic matter and maintain tree performance. Plant and Soil 378(1):325-335

Potter MT, Heerema RJ, Schroeder J, Ashigh J, VanLeeuwen D, Fiore C (2012). Mature pecan orchard floor vegetation management: impacts on tree water status, nutrient content, and nut production. HortScience 47(6):727-732.

Saure MC (2005). Calcium translocation to fleshy fruit: its mechanism and endogenous control. Scientia Horticulturae 105:65-89.

Sharifi M, Reekie J, Hammermeister A, Alam MZ, MacKey T (2016). Effect of cover crops on yield and leaf nutrient concentrations in an organic Honeycrisp apple (Malus domestica 'Honeycrisp') orchard in NovaScotia, Canada. HortScience 51(11):1378-1383.

Shear CB, Faust M (1970). Calcium transport in apple trees. Plant Physiology 45:670-674.

Singh SK, Sharma M, Singh PK (2016). Combined approach of intercropping and INM to improve availability of soil and leaf nutrients in fruit trees. Journal of Chemical and Pharmaceutical Sciences $9(2): 823-829$.

Slatnar A,Licznar-Malanczuk M, Mikulic-Petkovsek M, Stampar F, Veberic R (2014). Long-term experiment with orchard floor management systems: influence on apple yield and chemical composition. Journal of Agricultural and Food Chemistry 62:4095-4103.

St Laurent A, Merwin IA, ThiesJE (2008). Long-term orchard groundcover management systems affect soil microbial communities and apple replant disease severity. PlantSoil 304:209-225.

Tahir II, Svensson SE, Hansson D (2015). Floor management systems in an organic apple orchard affect fruit quality and storage life. HortScience 50(3):434441.

TrompJ (2005). Metabolic processes. In: TrompJ, Webster AD, Wertheim SJ (Eds). Fundamentals of temperate zone tree fruit production. Backhuys Publishers, Nl pp 39-54.

Watkins CB (2003). Principles and practices of postharvest handling and stress. In: Ferree DC, Warrington IJ (Eds). Apples: botany, production and uses. CABI Publishing, Cambridgepp 585-614.

Webster AD (2005). Roots and root growth. In: Tromp J, Webster AD, Wertheim SJ (Eds). Fundamentals of temperate zone tree fruit production. Backhuys Publishers, NI pp 107-119.

Westwood MN (1995). Temperate zone pomology: Physiology and culture (ThirdEdition). Timber Press, Oregon, USA.

Yao S, Merwin IA, Bird GW, Abawi GS, Thies JE (2005). Orchard floor management practices that maintain vegetative or biomass groundcover stimulate soil microbial activity and alter soil microbial community composition. Plant and Soil 271:377-389. 